\title{
Uppskerum eins og við sáum
}

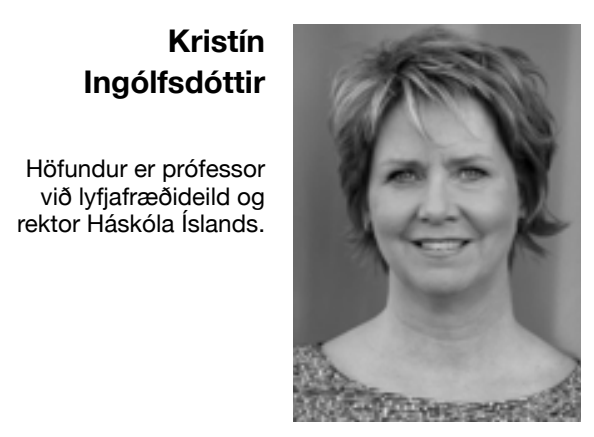

Árið 2006 kynnti Háskóli Íslands langtímamarkmið um afburðaárangur í menntun og vísindum. Leiðarljós var sú uppbygging sem átt hafði sér stað frá stofnun skólans og framtíðarsýn um mikilvægi öflugs háskóla til að stuðla að verðmætasköpun, hagsæld og heilbrigðu samfélagi. Fyrsta skref var að setja stefnu til fimm ára með ýtarlegri aðgerðaáætlun um hvað pyrfti að gera til að komast áleiðis. Nú á aldarafmælisári skólans, pegar ljóst er að langflestum áfangamarkmiðum sem sett voru fyrir fimm árum hefur verið náð, hefur Háskóli Íslands ítrekað langtímamarkmið sitt og sett stefnu til næstu fimm ára, til ársins 2016.

Starfsfólk og stúdentar heilbrigðisvísindasviðs ${ }^{1}$ Háskóla Íslands hafa með metnaði sínum, staðfestu og óprjótandi vinnuframlagi lagt verulega af mörkum til að skólinn næði markmiðum sínum, prátt fyrir erfiðar aðstæður. Pannig hefur fjöldi birtinga vísindagreina í kröfuhörðustu alpjóðlegu tímaritum og fjöldi tilvitnana tvöfaldast á fimm árum, hvoru tveggja staðfest af alpjóðlegum gagnagrunnum. Doktorsnemum í heilbrigðisvísindum hefur fjölgað verulega og fjármagn úr erlendum samkeppnissjóðum prefaldast. Pessi víðtæki árangur hefur náðst með gjöfulu samstarfi við fjölmargar innlendar og erlendar vísindastofnanir og fyrirtæki. Árangurinn skilar íslensku atvinnulífi betur menntuðu fólki og eykur virðingu Háskóla Íslands á alpjóðavettvangi og gerir hann eftirsóttan til samstarfs.

Háskóli Íslands og Landspítali hafa um árabil átt nána samvinnu sem miðar að pví að efla kennslu og rannsóknir í heilbrigðisvísindagreinum og bæta pjónustu við sjúklinga og aðstandendur. Með pví að sameina krafta hafa pessar stofnanir átt mikilvægan pátt í að skapa hér afbragðsgóða heilbrigðispjónustu og skapað einn öflugasta pekkingarklasann í íslensku vísindasamfélagi. Nemendur í heilbrigðisvísindagreinum hafa fengið inngöngu til framhaldsnáms í bestu og kröfuhörðustu háskóla heims. Peir hafa almennt staðið sig mjög vel, vakið athygli og oft fengið tilboð um starf að námi loknu. Sendinefndir frá virtum háskóla- og spítalastofnunum hafa heimsótt Landspítala og Háskóla Íslands og óskað eftir samstarfi, bæði í kennslu og rannsóknum. Petta eru allt góðar vísbendingar um gæði náms í heilbrigðisvísindum.

Eitt stærsta samstarfsverkefni Landspítala og Háskóla Íslands um pessar mundir er bygging nýs háskólasjúkrahúss og húsnæðis fyrir heilbrigðisvísindadeildir skólans. Petta mun gjörbreyta aðstæðum á spítalanum og háskóladeildunum til hins betra og leiða til nánari sampættingar í starfi spítala og skóla. Petta gerir einnig fært að tengja betur saman starf heilbrigðisvísindadeilda skólans sem eru nú með starfsemi á mörgum stöðum.

Ef litið er 100 ár aftur í tímann, sést hvað framtíðarsýn, stórhugur og einbeittur vilji geta kallað fram. Háskóli Íslands var stofnaður árið 1911 við afar pröngar aðstæður í samfélaginu. Í fyrstu voru fjórar deildir starfræktar við skólann; guðfræðideild, læknadeild, lagadeild og heimspekideild. Fyrsta haustið innrituðust 45 stúdentar, par af ein kona, Kristín Ólafsdóttir, sem átti eftir að útskrifast sem læknir, fyrst kvenna. Háskóli Íslands er afar pakklátur íslenskum læknum fyrir að hafa gefið skólanum málverk af Kristínu til minningar um frumkvöðul og afrekskonu. Margt hefur breyst frá pví Kristín innritaðist í Háskóla Íslands. Stúdentar eru nú 14.000 og konur eru í meirihluta á öllum námsstigum, par á meðal í doktorsnámi. Deildir skólans eru orðnar 25 talsins og skólinn hefur próast í að vera alpjóðlegur rannsóknarháskóli.

Íslendingar hafa náð mikilvægum árangri í uppbyggingu heilbrigðiskerfis og vísindapekkingar sem er bakhjarl pess. Um fátt ríkir meiri sátt í samfélaginu en mikilvægi heilbrigðiskerfisins og pess að pað pjóni samfélaginu öllu. Pví er brýnt að standa vörð um pann árangur sem náðst hefur og halda sókninni áfram. Sum viðfangsefnin eru pekkt, svo sem krabbamein, lífsstílssjúkdómar, öldrunarpjónusta, lyfjaónæmi, geðsjúkdómar og fleira. En við verðum einnig að byggja upp heilbrigðismenntakerfi sem gerir fært að fást við ný og ópekkt viðfangsefni. Umfram allt verðum við að leggja sérstaka áherslu á að styðja við afreksfólk á sviði vísinda. Hver einasta íslensk fjölskylda nýtur pjónustu heilbrigðiskerfisins. Við viljum að pessi pjónusta sé framúrskarandi. Раð verður hún ef stjórnvöld og peir sem bera ábyrgð á menntun, vísindum og pjónustu heilbrigðiskerfisins sameinast um skýra framtíðarsýn og ásetning um uppbyggingu af metnaði.

\section{Heimild}

1. Ingólfsdóttir K. Nýtt heilbrigðisvísindasvið Háskóla Íslands og háskólasjúkrahúsið Landspítali. Læknablaðið 2008; 94: 657 .

Harvest as we sow

editorial written on occasion of University of Iceland's centennial. Kristín Ingólfsdóttir - President and Rector of University of Iceland. 